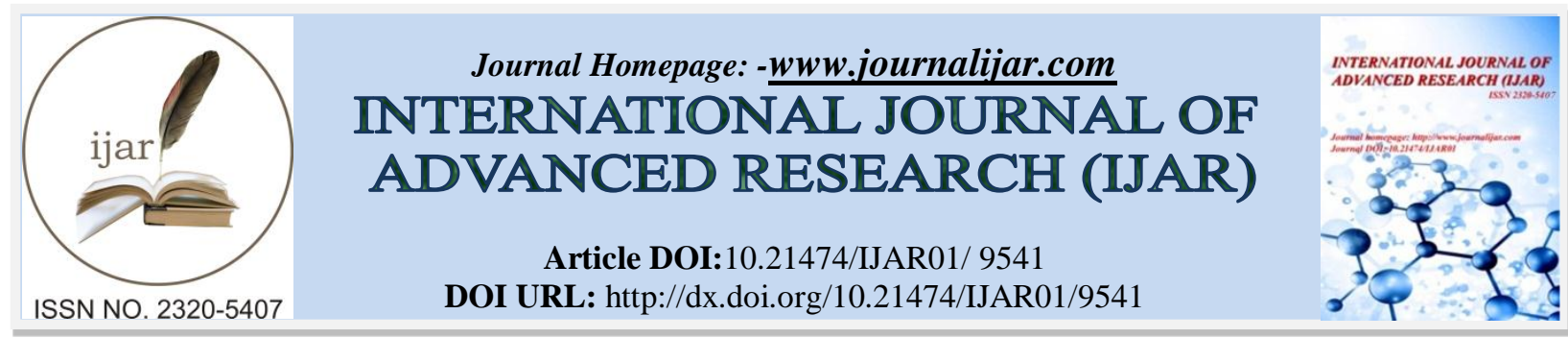

RESEARCH ARTICLE

\title{
URGENCY OF COASTAL AREA DEVELOPMENT.
}

\section{Hendry John Piris ${ }^{1}$, M. Yunus Wahid ${ }^{2}$, Syamsul Bachri ${ }^{2}$ and Irwasyah ${ }^{2}$.}

1. Faculty of Law Univesity of Pattimura, Maluku, Indonesia.

2. Faculty of Law Univesity of Hasanuddin, Sulawesi, Indonesia.

\section{Manuscript Info}

Manuscript History

Received: 08 June 2019

Final Accepted: 10 July 2019

Published: August 2019

Key words:-

Development, Coastal Areas.

\begin{abstract}
The urgency of coastal area development. This research aims to realize the development of coastal areas as part of the Integrated maritime Development area. The research method used in this study is empirical research studies.

The results of this research show that it is necessary to build coastal areas as part of the integrated and sustainable naval development, starting from the planning, implementation, supervision, control and evaluation phases. Synergistically that the management of natural resources in the marine environment does not damage the environment and the management of natural resources in the coastal areas does not exceed the environmental capacity, because the coastal region becomes a component of life Land and at sea. Principally the development of coastal areas to support the natural resources ecosystem both in the sea and in the land area to improve welfare.
\end{abstract}

Copy Right, IJAR, 2019,. All rights reserved.

\section{Introduction:-}

Implementation of the development of the life aspects of the nation, namely the political, economic, socio-cultural, and security defence planning, thorough, directional, integrated, gradual and sustainable to spur the increase of national ability in order to realize a parallel life and equal with the more advanced nations. Therefore, the real national development is a reflection of the will to continuously improve the welfare and prosperity of the Indonesian people.

Indonesia's rich coastal and ocean regions and its diverse natural resources have been utilized by Indonesians as one of the main sources of foodstuffs, especially animal proteins, since centuries. Meanwhile, the wealth of hydrocarbons and other minerals contained in this region has also been utilized to support development.

Maluku Province is one of the islands in Indonesia. Characteristics of heterogeneous regions with hundreds of islands make this vinsi different (unique) from other regions. Natural conditions in the domination of the sea should be a local strength or potential, again the development of the region based on its natural wisdom.

Many factors affect the development of coastal areas, thus inhibiting the development process is not optimally and sustainably. The development of coastal areas is often seen in sectoral, which is not studied maturely in the planning process. This led to the development of coastal areas often hampered by a global planning system. The development

Corresponding Author:-Hendry John Piris.

Address:-Faculty of Law Univesity of Pattimura, Maluku, Indonesia. 
of coastal areas should be examined in a mature way, should what it realizes is really an integrated development in accordance with the regional characteristics.

The development and management of coastal areas in Indonesia is a major challenge for all Indonesians. It takes a long strategy and process to change the new mind or paradigm in the marine sector to expand the coastal area, in Maluku itself should get special attention with villages or countries scattered in the region Coastal 1198 (not added to the hamlet) ${ }^{1}$. Through special attention, the Government of Maluku province established regional Regulation Number 10 year 2013 about the management of coastal regions and these small islands, as a consequence the issuance of law 27 years 2007 on the management of Coastal and small islands. According to Rokhmin Dahuri, the process of paradigm change in maritime development should consider the success factor and failure of a development policy or influence of outside factors that interact intensively with the activities of Development undertaken.

Sustainable use of resources professionally and sustainably means that the utilization of such resources must be done by observing the ability to meet the current needs, without ignoring the interests of the generation Will come.

The central government continues to encourage the provincial government to promptly complete the manufacturing of regional regulations zoning plans and small islands (RESEPSI).

Meanwhile, the 17 provinces that already have regulations zoning plans and small islands (RESEPSI) Regional Regulations, are North Sulawesi, West Sulawesi, Central Sulawesi, Gorontalo, West Nusa Tenggara, East Nusa Tenggara, Lampung, West Sumatra, East Java, Central Java, Special region of Yogyakarta, South Kalimantan, West Kalimantan, central Kalimantan, North Kalimantan, Maluku, and North Maluku² .

As a consequence of the archipelago, the coastal region of Indonesia is developing into a rapidly growing region, considering that coastal areas can provide high-accessibility, relatively inexpensive spaces compared to Land space on it $^{3}$. Based on this fact, it can be said that coastal management is an important component that needs to be considered in supporting development in Indonesia.

It concerns the boundaries of Regency/city government, provincial government and the central government in the management of coastal areas. This illustrates that the policy of coastal area management is still within the boundaries of the administrative region. The issuance of law No. 27 year 2007 on the management of coastal areas and small islands answered the confusion with the concept of integrated coastal management.

Maluku as an archipelago region has its own characteristics. The development of an archipelago that physically has a limited source of land wealth when not well planned, can result in significant external impacts. The mistake in setting the policy steps taken through a development program designed against the region of the archipelago affects the regional development process ${ }^{4}$.

The development of islands characterized by the archipelago must develop through a regional zone in an integrated area for regional development.

The Management and Zoning Plan (MAP) will guide the organizer in the arrangement of zoning of conservation areas (core zones, utilization zones and sustainable fisheries zones and other zones) and develop strategies and conduct activities Management, both in the long-term (20-year), medium-term (5 years) and implementation of activities in the annual plan. The planned management plan is required to contain region zoning ${ }^{5}$.

${ }^{1}$ Esther Kembauw, Lexy Sinay, Aphrodite M. Sahusilawane, Maluku economic development, Deepublish (Publisher Group CV Budi UTama, Yogjakarta, p 91

${ }^{2}$ https://www.mongabay.co.id/2019/04/16/pessnya-management-zonation-pesisir-dan-pulau-pulau-kecil/ accessed 2 april 2019

3 Bengen, D.G. 2000. Introduction and management of mangrove ecosystems. Coastal and Marine Resources Research Center IPB. 58, p. 22

${ }^{4} \mathrm{~J}$. Matakena, head of the economic section of Maluku Province, interview on November 22, 2018

${ }^{5} \mathrm{https} / / /$ surajis.wordpress.com/2015/07/24/management-and-zoning-area-conservation-national-water management plan / March 23, 2019 
The coastal region has a strategic value because it contains potential coastal resources of both biological and nonbiological resources, as well as environmental services that are very vulnerable to a variety of changes due to development. Similarly, it is vulnerable to natural disasters that may occur in coastal areas that form tidal waves (tsunami), floods, erosion and storms.

Coastal areas have a strategic meaning as it is a transitional area between sustainable land and sea ecosystems. In this coastal area there are coastal resources in the form of natural resources and very rich environmental services. The wealth of coastal resources creates an appeal for various parties to exploit it and various stakeholders to regulate its utilization. These resources can be divided into four categories, namely: (1) resources can be recovered (renewable resources) such as fish resources, mangrove and coral reefs; (2) Resources can not be recovered (nonrenewable resources) such as mineral resources, sea sand and salt; and (3) marine environmental services such as marine tourism, sea transportation and marine energy such as ocean thermal Energy conversion (OTEC); and (4) the precious thing drowned ${ }^{6}$.

Today's approach to development requires a regional development approach based on domestic resources. Domestic resources in question include resources in a broad sense that includes physical-natural resources, human resources, artificial resources, and social resources. The need for a development planning approach that is completely based on the potential of domestic and local human resources, along with local development outcomes, including the availability of physical and social infrastructures (institutional) Existing domestic. This approach requires identifying the base sectors (base sectors) which will be the driving forces sectors of the region's economic activities. Therefore, it is necessary to evaluate the regional resources and compare them with the surrounding territories so that they can be identified by the comparative and competitive advantages of the region.

Along with the law of the Republic of Indonesia Number 23 year 2014 about regional government chapters 27 and 28 about the province characterized by the archipelago. Maluku Province as a province that is given the authority to manage natural resources include exploration, exploitation, conservation and management of marine wealth outside of kerosene and natural gas, administration arrangement, spatial arrangement and participating and hold the authority of the Sea and defend the authority of the State. At law No. 1 of 2014 on the change of law No 27 year 2007 on the management of coastal areas and small islands in article 23, utilization of small islands and surrounding waters prioritized interest Conservation, training education, research and development of marine cultivation, fisheries and marine business tourism and fisheries industry sustainably.

In accordance with the regulation No. 16 of 2012 about the plan spatial planning of the province of Maluku 20132033 that Maluku as an archipelago province. The island cluster is a pattern of the division that is divided according to the physical condition of the region which is the archipelago area with the aim to create an optimal and efficient pattern, as well as equitable in service facilities services ${ }^{7}$.

\section{Methodology:-}

Legal research that serves to be able to see the law in real sense and examine how the legal work in a legal Research society environment is an empirical research law. The legal research taken is from the facts that exist in a society, legal entity or government body, based on the type of research referred to, the data obtained through interviews, with direct observation at the research site Includes the area of Ambon City, Buru Regency, and West Seram regency. The data sources used include primary and secondary data. Primary Data is obtained directly from the research site either through interviews, as well as observations.

\section{Research and Discussion Results:-}

\section{Spatial Arrangement as a Coastal Area Integration}

Within a decade there is a tendency that coastal regions and small islands are prone to damage due to people's activity in utilizing their resources or by natural disasters. In addition, the accumulation of various exploitation activities that are partially/sectoral in coastal areas and small islands or the impact of other activities in the coastal

\footnotetext{
${ }^{6}$ Speech from the Minister of Maritime Affairs and Fisheries of the Republic of Indonesia at the Seminar on Integrated Coastal Resource Management, UNDIP Semarang, 7 October 2004, Pages: 1

7 Esther Kembauw, Lexy Sinay, Aphrodite M. Sahusilawane, Maluku economic development, Deepublish (Publisher Group CV Budi Utama, Yogjakarta, 2015, p 93
} 
areas supported by existing legislation often raises Damage to coastal resources and small islands. The existing legislation is more oriented towards the exploitation of coastal resources and small islands without regard to resource sustainability. Meanwhile, the strategic value awareness of the sustainable, unified, and community-based management of coastal areas and small islands is relatively lacking.

Lacking the rights of indigenous/local people in the management of coastal resources and small islands such as Sasi, Mane'e, Commander Laot, Awig-Awig, limited space for community participation in the management of coastal resources and islands Small indicates that the principle of management of coastal and integrated small islands has not been integrated with development activities of various sectors and regions. The coastal management system has not been able to eliminate the factors causing damage and has not yet given the opportunity for biological resources to be able to recover naturally or non-biological resources substituted with other resources.

Therefore, the uniqueness of coastal areas and small islands vulnerable to developing conflict and limited utilization access for coastal communities and small islands, needs to be managed properly so that the impact of human activity can be controlled and Coastal areas are preserved for conservation. Accordingly, the objectives of the Buru district development are contained in the vision and mission of development, as well as the results of the analysis of potential and the support of the territory there are limitations in human resources to utilize the potential resources that exist Optimal utilization of the pattern for the utilization of the Buru Regency area. Regional space utilization basically divide the area over two types of utilization it cultivation area and protected area, this area is to be utilized to be used according to function, characteristic, potency and support capacity of the region, protected area Among them: The protected forest area of $11,039,3 \mathrm{Ha}$ and a cultivated forest of 315.830 hectares of Airbuaya subdistrict ${ }^{8}$. There is also a local area of protection which is an area that must be freed from physical development in special object protection efforts.

In addition, the Government of Buru also set;

1. Natural Sanctuary/Nature reserve area,

2. The area of natural decay which is utilized as a location of natural pelesterain covering plants and natural ecosystems,

3. Disaster prone areas,

4. Cultivation Area

5. Development area ${ }^{9}$.

The community needs to be encouraged to manage its coastal areas well and which has succeeded in needing to be incentivized, but the damaging needs to be sanctioned. The norms for coastal and small islands management are organized into the scope of planning, utilization, management, control, and supervision, taking into account the norms set out in other rules of abuse. As Act No. 26 of 2007 concerning Spatial Arrangement (State Gazette of the Republic of Indonesia year 2007 Number 68, Supplement to State Gazette of the Republic of Indonesia number 4725). The norms of coastal and small islands management that will be loaded are focused on the legal norm that has not been regulated in the existing regulatory system or is more specific than the general arrangement that has been laid down. The norms will give the government, the public and the private role as stakeholders in both regional interests, national interests, and international interests through an integrated area management system. In accordance with the nature of the unitary State of the Republic of Indonesia as a law country, the development of coastal and small islands management systems as part of sustainable development of the environment must be given a legal basis Clear, assertive and thorough to ensure legal certainty for the management efforts of coastal areas and small islands. The basis of the law is based on Pancasila and the Constitution of the Republic of Indonesia year 1945.

The management of natural resources that exist so far, is increasingly realized not in accordance with the values of sustainable natural resources utilization. Where, in this ongoing basis, it includes at least four basic things:

1. Efforts to meet human needs supported by the ability to support the ecosystem.

2. The efforts to improve the quality of human life by protecting and continuing.

3. Efforts to improve the human and natural resources that will be needed in the future, and

4. Efforts to bring human needs across generations.

${ }^{8}$ Strategic Environmental Assessment (SEA) for the 2017-2022 Regional Medium Term Development Plan (RMTDP) for Buru Regency, p 57

${ }^{9}$ Ufi samal, interview with Buru Bappeda Secretary, December 2, 2018 
The layout referred to in article 14 of the Environmental management protection legislation must be understood as the Regional Spatial Plan as stipulated in the Spatial Law. To preserve the functioning of the life and safety of the community, every regional spatial planning must be based on the Strategic Environmental Assessment (article 19 paragraph 1) of the Environmental Protection Protection Act. Further affirmed that regional spatial planning is established with regard to the carrying capacity and capacity of the environment (article 19 paragraph 2) of the Law on Environmental Management Protection.

The explanation of this article states "Quite clearly", so it requires a separate analysis to complement it. Article 19 This Environmental Management Protection gives at least two clues:

First : spatial plans should base itself on Strategic Environmental Assessment, which means anyway that means that the government and the area cannot compose/establish spatial plans before first compiling the Strategic Environmental Assessment (SEA)

Second : spatial plans should pay attention, in the sense of adjusting to the carrying capacity and capacity of the environment (the potential of the region) Kesemuannya is aimed at preserving the environmental function.

The sense of spatial is the form of structure and pattern of space (article 1 UUPR No. 26 year 2007). As a comparator, in article 1 point 2 of the law No 24 year 1992 (old UUPR) declared "spatial is a structural form and a spatial utilization pattern either planned or not". When the second is observed in spatial defences given in the two Spatial Planning Law (SPL), it appears that given by Spatial Planning Law (SPL) 1992 is closer to the reality than the new. In this spatial or spatial plans is determined the resources (natural resources and artificial resources) so that the utilization can be controlled according to the designation ${ }^{10}$.

Law No. 26 of 2007 on space layout underlined that the territory of the unitary State of the Republic of Indonesia which is an archipelago-based archipelago country that includes land space, sea space, and air space. The 26-year law of 2007 also mandated the importance of its management efforts wisely, effectively, and successfully used in the rules of spatial arrangement so that the quality of space can improve public welfare and social justice.

In this context, spatial arrangement is an approach in regional development aimed at improving the quality of people's welfare and environment through regional management efforts.

Menkinprawil explained the approach of spatial arrangement in relation to the development of the region consists of three interconnected processes, namely : the process of spatial layout planning, which resulted in a plan of spatial layout that is a form of intervention that is done so that human interactions/beings living with the environment. Article 1 Number 1 act No. 26 year 2007 concerning; Spatial arrangement, which is meant by space: "The containers that include land space, sea space and air space include the space in the Earth as a unity of territory, where human and other beings live activities and nurture their survival"

Provisions of article 1, number 2 of law No. 26 of 2007 on the arrangement of space referred to as spatial is "structural form of space and patterns of space".

As the meaning of the structural form of space utilization is the arrangement of the elements of the formation of environmental space and the social environment, a hierarchical artificial environment related to one another, while the meaning of the pattern Space utilization includes the location patterns of the distribution of agricultural industry work and the use of urban and rural land where the layout is a planned layout while the layout is not a directory Naturally occurring spaces such as streams, caves, mountains and others.

Furthermore, the article 1 of the number 5 that is meant by the arrangement of space is "a process of spatial planning, space utilization, and control and utilization of space".

${ }^{10}$ A. M Yunus Wahid, Introduction to Environmental Law, Primamedia, Jakarta, 2018, p. 2010 
Meanwhile, according to D.A. Tisnaamidjaja, the meaning of space is the physical form of the region in the geogarafical and geometric dimension which is a container for human beings in carrying out its life activities in a decent quality of life ${ }^{11}$.

The space as a place to establish human life as well as a natural resource is one of the gifts of God to the nation of Indonesia. Thus the area of Indonesia as an asset that must be utilized by the Indonesian people and nation is coordinated, integrated and as effective as possible by observing other factors such as economic, social, and culture Hankam and environmental sustainability to encourage the creation of a harmonious and balanced national development.

Since the 12-mile sea governance was returned to the province, hence the use of space by the provincial government, there should be maximised development planning and there is a mature envoation for the utilization of sea and land space in coastal areas ${ }^{12}$.

Furthermore, in the Decree of the Minister of Settlement and infrastructure of the region No. 327/KPTS/2002 quietly stipulation six, the guidelines for space determination, which is meant by space is;

"The container that includes the land space, the ocean room, the air space as a unity of the land of people and other living beings living and doing activities and maintaining its survival."

As outlined above in article 1 of law No. 26 of 2007, stating that space is divided into several categories, including:

1. The land space is the space located above and below the surface of the land, including the surface of ground water and the land side and the lowest sea line,

2. The Ocean Room is a space located above and below sea level that starts from the side of the sea from the bottom side of the ocean line including the seabed and the earth underneath, where the Indonesian state has its jurisdiction.

3. Air space is a space located above the land space and or the ocean space around the country and attached to the earth where the Indonesian state has its jurisdiction.

\section{Spatial planning}

To implement the development there must be a legal update which is a system, necessary planning ${ }^{13}$. The process of spatial planning, space utilization, and control of space utilization associated with each other are sequential. The understanding that this system is a cycle causes the results obtained from the spatial planning process is placed as a reference of the activities of utilization and control of space utilization. Based on this, the regional spatial plan is a formal manifestation of the policy, plan, and Programme (PPP) of reference that governs the spatial arrangement of a particular region.

In the implementation, differences in the handling and specific characteristics of a region unit distinguish the type of regional spatial plan (RTRW). An spatial plans governing a wide area unit contains more strategic and general direction and reference than spatial plans governing smaller units of the region. Consequently, the wider the set area, the longer the timeframe dimension (time-frame) that the rule can cover.

Processing a potential area, of course, first created design planning. So that regional development directives can be controlled and stay in line with local city RTRW. It will create synergities for development objects, so that their existence can support each other. Similarly, the city of Ambon, which is currently promote the process of development in various sectors in the region. The existence of a planned and measured guide will be the right footing in realizing Ambon Manisse who is ready to fulfill the era of globalization.

Ambon is a city located in the Leihitu Peninsula and Leitimur Peninsula has an interesting advantage and uniqueness. Ambon Island where the city of Ambon is located is part of the Maluku islands that are the islands of

${ }^{11}$ I. Supardi, Environment and Sustainability, Alumni, Bandung, 1985, p. 63

${ }^{12}$ Korebima, Interview with NGO Bima on December 12, 2018

${ }^{13}$ Law No.25 of 2004, Regarding the National Development Planning System in article 1 number 1, planning is a process for determining appropriate future actions, through a sequence of choices, taking into account available resources. 
the volcanist arc so that in general the city of Ambon has a region consisting mostly of hilly areas and steep smears. An area of $\pm 186.90 \mathrm{~km}^{2}$ or $73 \%$ of its area can be categorized as steep with a slope above $20 \%$ and an area of \pm 55 $\mathrm{km}^{2}$ or $17 \%$ of its region which can be classified flat or sloped with less than $20 \%$ slope. With a coastline of 102.7 $\mathrm{km}$, it has an area that comes in direct contact with the sea which is quite long.

Ambon as a city located on the coast, which has a hilly and rugged land characteristics, resulted in a land area optimized with spatial study as the main key to regional development ${ }^{14}$.

The growth of the population that crowded the coastal area, coastal areas and the coast are storing complex problems, because the community will come into contact with the ecosystem of beaches and sea. If not made a structured planning then the area will grow uncontrollably.

With the realization of the Gulf and coastal areas of Ambon as the "City of coastal and marine based service providers" Ambon City has a green open area that is still quite spacious. Over $70 \%$ of the total area is the natural green open space and the target green open space. While the percentage of area that utilized as protected forest is about $40 \%$, the potential of green open space Ambon city that still needs special attention, such as green space conservation and spatial plans policy about Land utilization in the city. It is intended for development to be in the corridor of preservation and prevention of damage to green open spaces ${ }^{15}$.

The need for Strategic environmental Studies (SES) is a form of strategic action in guiding, directing, and guaranteeing the negative effects on the environment and Sustainability considered in the plan policies and spatial programs. Its position is in the decision-making niche. Because the cycles and forms of decision-making in spatial planning are not always obvious, the benefits of Strategic environmental Studies are specific to each spatial plans. Strategic environmental Studies can determine the substance of spatial plans, can enrich the process of drafting and evaluation of decisions, can be used as complementary methodological instruments (complementary) or supplementary (Suplementer) of the description RTRW, or a combination of some or All the above functions.

The principles of the underlying sustainability principle of the Strategic Environmental Assessment for spatial arrangement are :

1. Interdependency emphasizes consideration of the linkage between one component and another, between one element to another, or between one variable biophysical with biological variable, or relation between local and global, Relations between sectors, between regions, and so on.

2. Balance (equilibrium) emphasizes the application of balance between aspects, interests, and interactions between living creatures and living spaces, such as the balance of development rate with the carrying capacity and the capacity of the environment Life, balance utilization with protection, recovery and so forth.

3. Justice to emphasize that policies, plans and programs do not result in restrictions on access and control over natural resources, capital and infrastructure, or knowledge and information to a group of people Certain.

\section{Strategy of Maluku Coastal Areas}

The archipelago area has several obstacles in development. Therefore, a good understanding of the characteristics of the archipelago community is crucial to the success of the development of the islands area.

The development of characteristic islands such as Maluku which is dominated by small islands must be based on each region's Karakatek, taking into consideration such things as :

1. Wide territorial waters should pay attention to the characteristics of the sea as regional development

2. Excessive exploitation of development but not supported by land

3. Prone to natural disasters that threaten safety

4. Isolated and isolated to the development of

5. Number of landmasses reduced, due to global warming

The islands in the Maluku region generally have different characters. The difference in the character is due to geographical, physical, climate, social, cultural and ethnic differences as well as the economic development phase, this needs to be done in order for the harmonization to accelerate development according to the target.

\footnotetext{
${ }^{14}$ NN. Sahureka, Interview with the Head of Structuring section on November 1, 2018

${ }^{15}$ Ambon City City Water Master Plan Planning
} 
Development in areas dominated by small islands must be based on the character of each region, most specifically Maluku, the development of the territory applied by the Maluku provincial government to accelerate the economic growth of small islands should It was described as ' the concept of an island cluster, with this the development of a certain character to answer the area of each region.

The main challenge of Maluku Province as an island province in improving the economy and kesejahteraaan of society is connectivity. With an area of 712,480 Km2 and 1412 Islands, Tetanu takes a fee that does little to unlock the access of each island. Good sea access and also land access area $92.4 \%$ of the area of Maluku consists of the sea, the remaining $7.6 \%$ is land with coastline reaches $10,630 \mathrm{~km}$.

The West Seram district is a protected forest, nature reserve, and marine Nature Park. Based on a map protected area distribution 1:250,000 identified 4 areas that are protected in the SBB area namely Gunung Sahui Nature Reserve, Pulau Kasa Nature Reserve and Kotania Teluk Alam Natural Park, dismaping It is also the development of the archipelago area Maluku province consisting of islands separated by the sea is focused on a particular area of the city of Ambon.

\section{Conclusion:-}

1. Maluku Province as an archipelago province by using the pattern of the island cluster to divide the region according to the physical condition of the region that is the archipelago area with the aim to create an optimal and efficient pattern and there is equalization and Facility services in addition to the province of Maluku also develops the potential of the region by developing existing and new growth centres, the development of the region-based island clusters and the potential maritime economies then need the agency Planning and development of Maluku provincial areas to make the acceleration of islands-based generation.

2. In the development of spatial areas in Maluku as part of the unitary State of the Republic of Indonesia need to be improved management wisely, empowered and successful to be guided by the rules of phone arrangement so that the quality Space area can be awake to the general welfare and social justice pursuant to constitutional 1945.

3. Development and development of the characteristic region of the archipelago such as Maluku must have a separate study of the strategic Environmental studies can determine spatial plans substance, can enrich the process of drafting and evaluation of decisions, can is utilized as complementary or supplementary methodological instruments (Suplementer) of the description of spatial plans substance, or a combination of some or all of the functions.

\section{Bibliography:-}

1. M Yunus Wahid, Introduction to Environmental Law, Primamedia, Jakarta, 2018.

2. Bengen, D.G. 2000. Introduction and management of mangrove ecosystems. Center for the Study of Coastal and Ocean Resources of IPB.

3. H. Juniarso, Achmad Sodik, Spatial Law in the concept of Regional Autonomy policy, Nuance, 2016

4. Supardi, Environment and Sustainability, Alumni, Bandung, 1985

5. Esther Kembauw, Lexy Sinay, Aphrodite M. Sahusilawane, Maluku economic development, Deepublish (Publisher Group CV Budi UTama, Yogjakarta.

6. Law No.25 of 2004, Regarding the National Development Planning System.

7. Law No. 26/2007 concerning Spatial Planning (Statute Book of the Republic of Indonesia No. 68/2007, Supplement to Statute Book of the Republic of Indonesia No. 4725).

8. Law Number 27 of 2007 concerning Management of Coastal Areas and Small Islands.

9. Speech from the Minister of Maritime Affairs and Fisheries of the Republic of Indonesia at the Seminar on Integrated Coastal Resource Management, UNDIP Semarang, 7 October 2004.

10. J. Matakena, head of the economic section of Maluku Province, interview on November 22, 2018.

11. Kore Bima, Interview with bima NGOs on November 12, 2018.

12. Ufi samal, interview by Bappeda Buru secretary, 2018.

13. Strategic Environmental Assessment (SEA) for the 2017-2022 (Regional Medium Term Development Plan (RMTDP).

14. NN. Sahureka, Interview with the head of the Structuring section on November 1, 2018.

15. Ambon Front City Water Master Plan Planning. 